\title{
O PROGRAMA ÉTICO ANTONIANO PARA O CLERO REGULAR
}

José Antônio de C. R. de Souza*

SINTESE - O presente trabalho analisa o programa ético de santo Antônio no que se refere ao modo de vida do clero regular. O texto básico é o dos 'Sermones dominicales' e dos 'Sermones festivi'. Neles percebe-se que, para o santo,o clero secular, o clero regular, os leigos e a 'Societas Christiana' precisavam de uma reforma dos costumes, de acordo com a reforma pastoral, moral e religiosa proposta pelo IV Concílio de Latrão (1215) para toda a Cristandade, e implementada pelos papas Honório III e Gregório IX, tendo como agentes pastorais os dominicanos e os franciscanos.

PALAVRAS-CHAVE - Santo Antônio. Sermões. Ética. Reforma dos costumes. Clero.
ABSTRACT - This study analyses St. Antonio's ethical program for the way of life of the regular clergy, based in his ideas contained in his Sermones Dominicales and Festivi, according his conviction that the secular and regular clergy, the laymen and the Societas Christiana needed of a reform of the customs, and also, according the pastoral, moral and religious program of reform of the customs, proposed by the IV Lateran Council (1215), for all Christians and the society, and implemented by the popes Honorius III and Gregory IX, whose pastoral agents was the Dominicans and the Franciscans.

KEY WORDS - St. Antonio. Sermons. Ethics. Reform os customs. Clergy.

O tema deste Congresso, Homem e Natureza no Pensamento Medieval, articula-se muito bem com o pensamento antoniano. De fato, em sua opera, constituída pelos Sermones Dominicales e Festivi deparamo-nos, de um lado, com uma enorme quantidade de exemplos tirados dos reinos mineral, vegetal e animal ${ }^{1}$

* Professor titular aposentado da Universidade Federal de Goiás - UFG. Bolsista do Conselho Nacional de Desenvolvimento Científico e Tecnológico - CNPq - do Ministério da Ciência e Tecnologia, Brasil, e do Instituto Camões.

1 A propósito, cfr. I. SILVEIRA O.F.M, in "Santo Antônio pregador modelo de evangelizador", RHEMA 4 (1995): 31, diz o seguinte: "S. Antônio cita várias vezes exemplos da natureza... Treze da mineralogia, cinqüenta e um da botânica, trinta e sete de animais, vinte e duas de aves, doze de répteis. Descreve a natureza de vários desses seres, baseado na ciência do tempo, mas com a intenção de ilustrar o que dizia...". Essa característica dos escritos antonianos tem sido tratada por muitos autores, dentre os quais salientamos, Maria C. P. MONTEIRO, Santo António de Lisboa. Da Ciência da Escritura ao Livro da Natureza, Lisboa, IN-CM, 1997, 250 p.; José A. A. de CASTRO, O simbolismo da natureza em Santo António de Lisboa, Porto, UCP/Fundação Eng. António de Almeida, 1997, 252 p.; Idem, "Fontes do naturalismo antoniano (A metodologia antoniana e as abordagens de Aristóteles, Plínio e Isidoro de Sevilha)", Actas Congresso Intemacional Pensamento e Testemunho $8^{\circ}$ Centenário do Nascimento de Sto. Antonio, UCP/Familia Franciscana Portuguesa, Braga, 1996, vol., I: 335-347; J. HAMESSE, "L'utilisation de florilèges dans l'oeuvre d'Antoine de Padua. A 
e aplicados ao ser humano. Por outro, o Santo também está sempre a dirigir-se aos homens, preocupado que estava com a reforma dos costumes, ${ }^{2}$ como ele próprio o diz, numa passagem do sermão alusivo ao $9^{\circ}$ Domingo depois de Pentecostes:

"O pregador, portanto, deve tirar dos úberes o leite da narrativa, para dele poder tirar a manteiga suavíssima da moralidade. Recorde-se que o leite consta de três substâncias. A primeira é o chamado soro aquoso; a segunda a nata; a terceira a manteiga. O soro aquoso significa a narrativa; a nata, a alegoria; a manteiga, a moralidade. Esta, quanto mais suave é, tanto mais suavemente penetra nos corações dos ouvintes, porque os costumes estão corrompidos. Por isso, 'deve-se ligar mais à moralidade, que informa os costumes, do que à alegoria, que ensina a fé, pois a fé, por graça de Deus, encontra-se difundida em toda a terra', [...] 0 sangue [...] significa a compunção das lágrimas, que vivificam e sustentam a alma, a fim de não cair em pecado [...]. O pecador, pois, enquanto se ordenha violentamente com a palavra da pregação, levantando para as alturas o seu espírito, tira sangue, isto é, denama lágrimas, por ter dissipado os bens do Senhor que the foram confiados [...]."

Ademais, estamos convencidos de que frei Antônio, engajou-se plenamente no programa de reforma dos costumes do clero regular e secular, da Igreja e da sociedade, estabelecido pelo IV Concilio de Latrão, ${ }^{4}$ (novembro de 1215), convoca-

propos de la philosophie naturelle d'Aristote, ibidem, vol., I: 111-124. Maria C. P. MONTEIRO, "A natureza no pensamento de Santo António de Lisboa", ibidem, vol., I: 71-85; Idem, Il "Liber Naturae" nella "lectio" antoniana. Atti del Congresso Intemazionale per l'VIII centenario della nascita di sant' Antonio di Padova (1195-1995). A cura di Fernando URIBE, Roma, Pontificio Ateneo Antonianum, 1996, 330 p. Paulo H. C. de SOUZA O.F.M, "Santo António e a Natureza", Itinerarium 155 (1996): 217-264; GANHO, Maria de L. Sirgado, "Homem e natureza em Santo António", Itineranum 155 (1996): 63-75; C. CORRAIN, "Simbolismi antoniani dal mondo della natura", Palestra del Clero, 74 (1995): 681-694; N. MUSCAT, "The 'Liber Naturae' as a surce of Revelation in the 'Sermones' of Anthony of Padua", Melita Theologica" (Rabat), 46 (1995): 37-49.

Sobre o caráter predominantemente ético dos Sermones de Sto. Antônio e a sua fundamentação cfr. a seguinte bibliografia básica: B. COSTA O.F.M. Conv., "La Teologia Morale di Sto. Antonio", S. Antonio Dottore della Chiesa, Atti delle due settimane antoniane tenute a Roma e a Padova nel 1946, Roma, Poliglota Vaticana, 1947: 360-381. L. ELDERS, "La Théologie Morale des 'Sermones Dominicales et Festivi de Saint Antoine', Atti del Congresso Internazionale di Studio sui Sermones di S. Antonio di Padova, a cura de Antonino Poppi, Pádua, Ed. Messaggero, 1982: 607-623. P. SCAPIN, "Capisaldi dell'antropologia antoniana", ibidem: 679-692; H.SANTIAGO-OTERO, "Fundamentación filosófica del pensamiento antoniano Perspectiva ética" Actas Congresso Intemacional Pensamento e Testemunho $8^{2}$ Centenário do Nascimento de Sto. Antonio, UCP/Familia Franciscana Portuguesa, Braga, 1996, vol., I: 99-110. A. MOSER O.F.M., "A Concepçāo Moral de Sto. Antônio de Pádua", Antônio homem evangélico na América Latina, Compilação das conferências apresentadas no $1^{2}$ Congresso Antoniano Latino-Americano, Ed. O Mensageiro de Santo Antônio, Santo André, 1996: 45-54.

3 Santo António de Lisboa Obras Completas, Porto, Lello \& irmão, 1987, vol. I: 760, 761, 762, ed. bilingue de Henrique Pinto REMA O.F.M. Cfr. também, Abade Guiberto, Quo ordine sermo fieri debeat, in PL 156: 26

4 Cfr. Conciliorum Oecumenicorum Decreta, Concilium Lateranense IV, ed. J.ALBERIGO, A. DOSSETI PERIKLE, P. JANNOU, C. LEONARDI, P. PRODI, Bologna, Istituto per le Scienze Religiose, MCMLXXIII: 235-265. Cfr. também A. Garcia y GARCIA, Garcia "La reforma de la Iglesia en tiempos de San Antonio de Lisboa". Actas do Congresso Internacional Pensamento e Testemunho $8^{2}$ Centenário do Nascimento de Sto. Antonio, UCP/Familia Franciscana Portuguesa, Braga, 1996, vol. II: 705-721. Com efeito, dos 70 cânones prómulgados pelo Concilio, os quais podem ser agru- 
do e presidido por Inocêncio III (1198-1216), face à decadência moral dos homens de então, reforma essa implementada por seus sucessores, Honório III (1216-27) e Gregório IX (1227-39), principalmente através da ação pastoral dos frades Pregadores e Menores, comprometimento esse que pode ser comprovado, não apenas pela supracitada passagem sermonária, mas também por sua atuação como pregador na Provença, no Milanês e no Veneto, (1224-31), e ainda, por sua atividade magisterial em vánios studia da Ordem, com vista a preparar os confrades para 0 ministerium do anúncio da Palavra, com o fito de promover a conversio e ou a reconversio dos seus contemporâneos. ${ }^{5}$

Por tais motivos, posto que justamente a opera antoniana reflete claramente todos esses aspectos, neste estudo escolhemos pontualmente abordar o programa ético ou de conduta moral que Antônio apresenta a um conjunto singular de seres humanos, os religiosos, os quais se propõem a viver os Conselhos Evangélicos, a via perfectionis, em comunidade, por amor a Cristo e aos irmãos, programa esse que, julgamos, estende-se perenemente ao clero regular de todos os tempos. Todavia, dada a própria natureza de seus Sermones, não encontramos neles um tratado sistemático acerca deste assunto. Por isso, inicialmente, tivemos de compulsá-los, a fim de recolher os seus ensinamentos, os quais, depois, os organizamos e os analisamos, tal como adiante será exposto. As fontes em que o Doutor Evangélico baseou-se, de um lado, o Novo e o Antigo Testamento, os textos dos Padres da Igreja, as Glosas às passagens bíblicas que utilizou. Por outro lado, estribou-se também no método exegético, então, em voga, ao qual ele próprio exercitou e aludiu na passagem há pouco citada, e em sua própria experiência. Aliás, recordemos que Antônio antes de tornar-se frade Menor foi cônego agostiniano, tendo vivido nos mosteiros de S. Vicente de Fora, em Lisboa, e em Santa Cruz de Coimbra (c. 1205-20), onde cultivou uma sólida formação intelectual. Ele, portanto, conhecia muito bem o comportamento dos monges e religiosos de seu

pados em vários blocos, consoante o seu núcleo comum, o $2^{\circ}$, por exemplo, versa a respeito da disciplina eclesiástica, compreende os cânones 6 a 13; o $3^{2}$, que concerne à reforma da conduta moral e pastoral do clero, abrange os cânones $14-22$; o $4^{2}$ bloco, que reúne os cânones 23 a 32 , trata das eleições episcopais e da concessão de beneficios eclesiásticos; o penúltimo bloco, englobando os cânones 63-66, concerne à simonia.

5 A propósito dessa visão historiográfica mais recente acerca de Sto. Antônio e sua participação no movimento Franciscano e do engajamento dos Menores no programa pastoral reformista da Igreja, cfr. os seguintes estudos: C. GASPAROTTO, "Perchè Sant'Antonio venne a Padova", II Santo, 5 (1965): 211-225. R. MANSELLI, "La Coscienza Minoritica di Antonio di Padova di fronte all'Europa del suo tempo", Atti del Congresso Intemazionale di Studio sui Sermones di S. Antonio di Padova, a cura di Antonino Poppi, Pádua, Ed. Messaggero, 1982: 29-35. T. LOMBARDI O.F.M. Conv., "Sant'Antonio di Padova Maestro di Teologia a Bologna. Il Problema degli Studi agli inizi dell'Ordine Francescano", ibidem: 797-817. C. LEONARDI, "Antonio di Padova e la questione francescana", Actas Congresso Intemacional Pensamento e Testemunho $8^{\circ}$ Centenánio do Nascimento de Sto. Antonio, UCP/Familia Franciscana Portuguesa, Braga, 1996, vol. I: 269-274. D. de AZEVEDO O.F.M., "O Capítulo Geral da Ordem dos Frades Menores em 1221 na vida de Santo António", ibidem, vol. II: 823-834. L.BERTAZZO O.F.M. Conv., "Santo Antônio nas Fontes Franciscana e sua inserção no pauperismo evengélico-minorítico das origens", Antônio homem evangélico na América Latina, Compilação das conferências apresentadas no $1^{2}$ Congresso Antoniano Latino-Americano, Ed. O Mensageiro de Santo Antônio, Santo André, 1996: 11-32. O. BERNARDI O.F.M., "O Franciscanismo de Sto. Antônio", Universidade São Francisco, Bragança Paulista, Cadernos do IFAN, 18 (1997): 45-77. 
tempo, ${ }^{6}$ e "na viragem eclesial do século XIII, quando o mundo das instituições monásticas e canonicais era agitado e contestado por novas formas de vivência evangélica, Santo António, com a força do amor de Deus e a ousadia da radicalidade evangélica, não se intimidava em denunciar e corrigir, do púlpito, alto e bom som, defeitos das ordens religiosas sem, todavia, lhes negar a validade [...]".?

Para começar, à guisa de ilustração, citemos, de passagem, algumas das denúncias acerca do mau comportamento dos religiosos, feitas pelo Santo: "Os gafanhotos, por causa do salto que dão, significam todos os religiosos, que, juntos os dois pés da pobreza e da obediência, devem saltar para a sublimidade da vida eterna. Mas infelizmente, com salto retrógrado, saíram do fundo do poço para a terra, e como se diz no Êxodo [X, 5] cobriram a superfície da terra. Hoje não se fazem feiras, não se celebram reuniões seculares ou eclesiásticas em que não encontres monges e religiosos. Compram e voltam a vender...Em causas judiciais, provocam partidos, litigam diante de juízes, contratam decretistas e legistas, convocam testemunhas, prontos a jurar com elas a favor de assunto transitório, frívolo e vão. Dizei-me ó fátuos religiosos, se nos Profetas ou nos Evangelhos de Cristo, ou nas Epístolas de S. Paulo, na Regra de S. Bento ou de S. Agostinho encontrastes estes litígios e divagações e se lestes ali clamores e protestos de causas judiciais, por assunto transitório e perecedouro. Muito pelo contrário, diz o Senhor aos Apóstolos, aos monges e a todos os religiosos, não aconselhando mas mandando, porque escolheram o caminho da perfeição, qual deve ser a regra para a sua vida, no Evangelho de Lucas [...]."

No entender do Santo, as transgressões dos monges e frades às respectivas Regras, era causada tanto por causa da omissão dos abades e priores, porquanto não só faziam vista grossa ao seu mau comportamento, bem como não os corrigiam, daí ele os advertir acerca do que os espera no futuro, dizendo "Escutem tam-

6 Terenzio DE POI "Teologia del Sacerdozio e della vita religiosa nei Sermoni Antoniani", Atti del Congresso Intemazionale di Studio sui Sermones di S. Antonio di Padova, a cura di A. Poppi, Pádua, Ed. Messaggero, 1982, p. 629: "Antonio [...] conosce bene un certo quadro di vita religiosa, al quale fa riferimento sempre com molta sicurezza [...]. Quando tratta della vita spirituale, che è fatta di preghiera, di contemplazione, di apostolato [...] nota che la via a questa vita ed esperienza spirituale è costituta essenzialmente da alcuni atteggiamenti e scelti particolari: l'umiltà [...] povertà, castità, penitenza, obbedienza. Cioè, sono le virtù tipiche, le scelte proprie e caratterizzanti della vita religiosa [...]."

7 Geraldo J. A. Coelho DIAS, O.S.B., "A Critica da vida religiosa por Santo Antonio e o elogio do Santo por Fr. Paio de Coimbra", Actas, Congresso Internacional Pensamento e Testemunho $8^{Q}$ Centenário do Nascimento de Sto. Antonio, vol. I, UCP/Familia Franciscana Portuguesa, Braga, 1996: 456.

8 Cfr. $2^{2}$ Domingo da Quaresma, vol., I: 143-144, e igualmente Lc VI, 27-33. O referido estudioso, citado na nota anterior, a propósito deste trecho, emite o seguinte ponto de vista, no mesmo artigo, p. 451-452: "Neste ponto como noutros ainda, talvez recordando a sua condição de desiludido da regra de S. Agostinho, que professara e deixara em Coimbra, Santo António parece conhecer e comungar daquela acrimónia que a Apologia de S. Bernardo despejara contra os monjes [sic] cluniacenses quando do aparecimento da reforma monástica de Cister. A referência às feiras parece mesmo citação (Apol. 26) e a truculência da linguagem latina é verdadeiramente semelhante; de resto, é sabido como Santo António conhecia e estava familiarizado com os escritos de S. Bernardo. Estranhamos, por isso, que os comentadores dos sermões antonianos, talvez por falta de conhecimento desta obra 'maldita' de S. Bernardo, nunca a refiram como fonte das diatribes de Santo António contra a vida monástica e canonical do seu tempo [...]." 
bém os Abades e Priores [...] se tiverem um monge ou um cónego soberbo, dado ao vinho e luxurioso se não o quiserem controlar nos seus vícios e o impedir de com o mau exemplo escandalizar, não somente ele morrerá na sua iniquidade mas também sereis castigado[s] eternamente", ' quanto, ainda, pelo mau exemplo que davam aos seus súditos. Com efeito, num trecho do sermão alusivo ao $22^{\circ}$ Domingo depois de Pentecostes, o Santo estribando-se numa passagem do profeta Ezequiel, VIII, 8-12, referente à má conduta ética dos israelitas, infiéis à aliança com Javé, e corrompidos pelos maus costumes e pela idolatria de seus vizinhos, compara as lideranças daquele povo, aí referidas, com muitos dos religiosos, abades e priores de sua época, os líderes espirituais dos fiéis, cuja vida e as obras, antes, deviam refletir os Sete Dons do Espirito Santo, mas, no entanto, ao contrário, vangloriosos tinham passado a cultivar a vanglória, e a adorar ou praticar os vícios da soberba, gula e luxúria. E pior do que isso, os abades e priores, ao invés de lhes darem bons exemplos e coibir a prática de tais vícios, na verdade, os praticavam junto com eles: [Os religiosos] "enfatuados [...] colocam-se diante das pinturas [...] [quer dizer] os fantasmas da soberba, da gula e da luxúria no espírito. Daí os répteis a clamar ai! ai! figuram os filhos e os sobrinhinhos; a abominação dos animais, a impureza das fornicações; os ídolos pintados, os parentes e amigos. Eis as pinturas que alguns religiosos do nosso tempo adoram...E o que é pior, Jeconias, isto é, o abade ou o prior [...] que deve proibi-las, encontra-se no meio deles e adora as mesmas pinturas [...]."

Para além disso, tais abades e priores, dado que o cargo que exerciam, permitia-lhes agir livremente, posto que não tinham de dar satisfação a ninguém, distribuiam à socapa os víveres e outros bens materiais aos seus familiares e amigos, bens esses que os fiéis, muitas vezes com bastante sacrifício, lhes haviam doado para o sustento deles e dos pobres. O turíbulo nas mãos, referido na predita passagem do profeta, representa "a provisão do mosteiro, em poder do superior, dada com o intuito de esmola e de sacrifício [...] mas estes companheiros de Judas, possuidores da bolsa do traidor [...] incensam as suas pinturas, quer dizer, dão os bens do mosteiro, que sãos dos pobres, aos seus parentes e a outras pessoas [...]". ${ }^{10}$

Essas poucas passagens da opera de Antônio mencionam bastante bem os pecados e outros vícios perpetrados pelos religiosos daquela época, e quiçá de nosso tempo. Mas, com razão, ele considerava que o pior pecado cometido pelos mesmos consistia em transgredirem parcial ou totalmente o tríplice voto, da pobreza, da castidade e da obediência, que haviam se proposto a praticar, buscando o caminho da perfeição evangélica ensinado e aconselhado por Cristo. Ademais, a transgressão de tais votos ainda era, não só um contra testemunho de vida para os demais fiéis, mas também um comportamento fingido ou hipócrita.

$6^{2}$ Domingo depois de Pentecostes, vol., I: 680.

$22^{\circ}$ Domingo depois de Pentecostes, vol., II: 292-293. Geraldo Coelho DIAS O.S.B., "A Crítica da vida religiosa por Santo Antõnio e o elogio do Santo por Fr. Paio de Coimbra", Actas, Congresso Internacional Pensamento e Testemunho $8^{2}$ Centenário do Nascimento de Sto. António, vol. I, UCP/Familia Franciscana Portuguesa, Braga, 1996, à p. 454, muito apropriadamente a respeito deste passo, diz que "António verbera os religiosos que, numa manifestação de nepotismo descarado, dão aos parentes o património do Crucificado [...]". 
Ora, os textos antonianos mais expressivos, no que respeita à conduta ética do monge e do frade, não importa a congregação a que pertença, como não podia deixar de ser, incidem justamente sobre o cerne da vida religiosa.Com efeito, num passo do sermão alusivo ao $4^{\circ}$ Domingo do Advento, cujo evangelho lido na missa fala sobre a pregação do Batista às margens do Jordão (cfr. Lc III, 2-4), o Santo, inspirando-se no versículo 'Endireitai as veredas de nosso Deus' (cfr. Is $\mathrm{XL}, 3$ ), e pondo-o em consonância com um outro trecho do profeta, em que ele diz 'a vereda do justo é direita, direito é o atalho do justo para se andar por ele' (XXVI, 7), explicita primeiramente em que consiste a vida religiosa, dizendo simbolicamente que a vereda ou caminho referido naquela passagem biblica representam qualquer congregação religiosa, a qual "é coarctada e restringida pelos votos de pobreza, continência e obediência...Portanto, ó religiosos, 'endireitai as veredas de nosso Deus' [...]". ".

Isto significa que todos os religiosos, pelo fato de terem procurado o caminho da perfeição evangélica devem precípua e efetivamente praticar sempre o tríplice compromisso pessoal e comunitário da pobreza, da castidade e da obediência, mostrando aos semelhantes que, apesar das solicitudes que o mundo lhes apresenta, é possível trilhar aquele caminho, por amor a Cristo e ao próximo. Noutras palavras, a experiência espiritual da vida religiosa exige, como nota Terenzio da Poi "distacco e abbandono del mondo e delle mete che il mondo mostra, la mortificazione di sè, l'umiltà. Però la vita religiosa è soprattutto, prima di tutto, amore di Dio, ricerca di Dio, amore personale di Dio persona: in primo luogo il Cristo, e in lui il Padre, nello Spirito Santo [...]". ${ }^{12}$

Em passagens de outros dois sermões dominicais o Doutor Evangélico explica em que consiste ou o que é esse caminho de perfeição. Num deles, ${ }^{13}$ por exemplo, comparando Cristo com o sol, astro esse que irradia fogo e calor, e que simboliza "o amor de Deus em que há [...] o calor da humildade, o brilho da castidade e a leveza da pobreza", diz que Ele veio à terra, onde há "a frialdade da soberba, a escuridão da luxúria, o peso da avareza", lançar-lhe o fogo de seu amor "porque opôs o calor da humildade à frialdade [...] da soberba [...] o brilho da castidade à escuridão da luxúria, a leveza da pobreza ao peso da avareza". Daí, Ele próprio ter declarado: "Se queres ser perfeito, vai e vende [...]", Mt XIX, 21. Com efeito, "o homem de espírito pobre é corredor ligeiro" que consegue acompanhar o DeusHomem. "De quanto tempo se alivia quem gosta de não possuir nada!", daí, a Sabedoria declarar nos Provérbios (IV, 11-12): 'Eu te mostrarei o caminho da sabedoria, guiar-te-ei pelas veredas da equidade (isto é da pobreza). Depois que tiverdes entrado nelas, os teus passos (os afectos) não serão dificultados, e correndo não encontrarás tropeço' [...]". ${ }^{14}$

$114^{2}$ Domingo do Advento, vol., II: 493-494.

"Teologia del Sacerdozio e della vita religiosa nei Sermoni Antoniani", Atti del Congresso Internazionale di Studio sui Sermones di S. Antonio di Padova, a cura de Antonino Poppi, Pádua, Ed. Messaggero, 1982: 630 .

14 $18^{\circ}$ Domingo depois de Pentecostes.

Ibidem, vol. II: 205-206. 
Portanto, quem abraça a vida religiosa, verdadeira e fundamentalmente impelido por um profundo amor a Deus, e se propondo a imitar Jesus, está disposto a dominar a sua soberba, sendo humildé e obediente à Regra, aos estatutos de sua Ordem e aos seus superiores; a renunciar ao casamento e aos prazeres da carne. praticando a virtude da castidade; a abrir mão dos bens materiais e do direito de propriedade sobre os mesmos, vivendo a pobreza voluntária.

De fato, o exercício da virtude da humildade leva o religioso a dominar a sua vontade e a descobrir e a aceitar os desígnios de Deus, através das determinações dos seus superiores, muitas das quais, inúmeras vezes, são difíceis de serem acatadas, por exemplo, quando ele é transferido de um lugar, em que se sentia feliz e realizado, para um outro que não conhece, etc. A virtude da pobreza por opção, à semelhança do comportamento de Cristo e dos Apóstolos, faz com que o religioso, paralelamente se exercite no desapego dos bens terrenos e do dinheiro, e se compadeça dos despossuídos ao seu redor, que não têm com o que se alimentar, vestir e calçar, e tampouco condições para procurar o Pão da Palavra e o Eucarístico, mais livremente possa dedicar-se a eles nos planos material e espiritual. Enfim, o religioso ao abrir mão do casamento, da paternidade ou da maternidade, aos quais a maioria dos seres humanos está vocacionada, coloca-se integralmente à disposição dos semelhantes, a fim de poder gerar mais filhos para Deus, através de seu ministerium.

O Santo Ulissiponense numa passagem dum outro sermão, ${ }^{15}$ inspirando-se, de um lado, na maneira de viver de João Batista, descrita por São Mateus, XI, 2-8, e de outro, num trecho de Isaías, XXXV, 1-2, em que está escrito 'A terra deserta e sem caminho alegrar-se-á, e a solidão exultará e florescerá como um lírio. Lançando germes, ela brotará copiosamente, e exultará de alegria e de louvores', pondo em acordo os dois textos, explica mais detalhadamente o que é a vida religiosa e como deve ser a conduta ética dos que a abraçam.

$O$ deserto simbolicamente e sob o aspecto moral significa a vida religiosa, que se alicerça na observância ou prática da "pobreza, castidade e obediência", da parte dos que optaram pela mesma. Por isso, no tocante ao voto de pobreza, "todo religioso que [realmente quer ser pobre] precisa em primeiro lugar, de renunciar a todos os bens exteriores; em segundo, não ter vontade de possuir coisa alguma; em terceiro, sofrer com paciência o incómodo da própria pobreza". As palavras 'deserta, sem caminho e solidão' denotam isso. De fato, "A vida de qualquer religioso deve ser 'deserta' pela total renúncia aos bens exteriores; 'sem caminho' para que não permaneça na sua vontade vestígio algum de possuir o que quer que seja". A solidão contribui para "que o religioso saiba ter fome e sede e padecer penúria". ${ }^{16}$ Por conseguinte, observa Costa Macedo, a "a pobreza voluntária como virtude $[. .$.$] trata-se de um estado de perfeição possivel do homem relativamente à$ sua relação com os bens terrenos...não é para todos embora permaneça como ideal para todos [...]". ${ }^{17}$

15

16

17

$2^{2}$ Domingo do Advento, vol. II.

Ibidem, vol., II: $459-460$.

J. M. da C. MACEDO, "Paupertas, Raízes e horizontes", Actas Congresso Internacional Pensamento e Testemunho $8^{\circ}$ Centenário do Nascimento de Sto. Antonio, UCP/Familia Franciscana Portuguesa, Braga, 1996, vol., II: 601. 
Reflitamos sobre as características essenciais do voto de pobreza apresentadas por Santo Antônio. Renunciar a todos os bens exteriores ou materiais significa explicitamente que o religioso abre mão do direito de propriedade e da possessão sobre os mesmos, e implicitamente, quer dizer, que ele não tem nada como se fosse seu, nem a comida, nem a bebida, nem os objetos pessoais, e tampouco as roupas e o calçado que usa. Noutras palavras, essa maneira de servir-se dos bens materiais, é designada por usus pauper e espelha em que consiste o espírito de pobreza, acerca do qual Antônio diz o seguinte: "O espírito do Senhor é o espírito de pobreza...poderosos são os verdadeiros pobres que não sabem o que é vacilar na prosperidade ou na adversidade, cujo espírito [...] investe contra a parede das riquezas [...]. O escudo, assim chamado por ocultar o corpo, é o espírito de pobreza que oculta a alma das frechadas dos demónios [...]."18

Daí, o Menorita Lusitano frisar que "os verdadeiros pobres de espírito contemplam o Filho de Deus, peregrino no caminho e glorioso na Pátria [...]. O Senhor consola com os Seus bens os privados de bens temporais [...] o deserto da pobreza exterior faz as delícias da suavidade interior [...]. Ó pobreza...as tuas delícias oferecem aos que te amam um sabor de eterna doçura...a verdadeira pobreza é sempre alegre [...]. ${ }^{n 19}$

Para além disso, é preciso igualmente que o religioso domine progressiva e quotidianamente o desejo, ou num grau mais intenso, a ambição de possuir qualquer bem que lhe agrade, inclusive o dinheiro, como se fosse algo próprio, de que pode dispor ad libitum a qualquer momento. Por último, o Santo julga que o religioso para crescer na prática da virtude em apreço, terá que, com resignação, padecer na própria pele das vicissitudes que ela traz consigo, a falta de alimento, de água para debelar a sede; de dinheiro para os obter; os conseqüentes mal-estar físico, o enfraquecimento corporal, a debilitação da saúde, acompanhada de doenças, etc.

Voltando ao texto do predito sermão, deparamo-nos com o Santo Ulissiponense, apoiado nas Glosas, a explicar simbólica e moralmente aquela passagem de Isaías, e outras mais, no respeitante ao voto de castidade. Em primeiro lugar, ele diz que o lírio figura a pureza do corpo, e depois, acrescenta o seguinte: 'Não diga o eunuco' o que se castrou, o que prometeu continência por causa do reino dos céus, 'Eis que eu sou um lenho seco, porque isto diz o Senhor aos eunucos: 'Aos que guardarem os meus sábados', a pureza de coração, que é o sábado do peito, 'e praticarem o que eu quero', a continência do corpo, da qual escreve o Apóstolo: 'Esta é a vontade de Deus, a vossa santificação, que cada um de vós saiba possuir o seu vaso', o corpo, 'em honra e santidade e abraçarem a minha aliança' que fizeram comigo no Baptismo, 'darei um lugar' de que se diz em S. João: 'Vou-vos preparar um lugar na minha casa' onde há muitas moradas $[\ldots]^{\prime 2}{ }^{20}$

\footnotetext{
$5^{\circ}$ Domingo depois da Páscoa, vol., I: 442.

$2^{2}$ Domingo do Advento, vol., II: 456-457.

$2^{2}$ Domingo do Advento, vol., II: 460-461. Cfr. também os comentários das Glosas aos passos bíblicos citados, e igualmente as próprias passagens: 1Ts IV, 4 e Jo XIV, 2.
} 
De seguida, o Santo Menorita, continuando a explicar moralmente aquela mencionada passagem de Isaías, diz que a verdadeira obediência se caracteriza por cinco atitudes ou comportamentos; da parte do religioso que optou por observá-la, a saber, ela é "humilde, devota, apressada, alegre, perseverante". Com efeito, "a humildade é o princípio de toda a boa acção. Devota [...], pois da humildade do coração procede a devoção da voz. Apressada [no cumprimento] da ordem...alegre na tribulação...perseverante no cumprimento do preceito". ${ }^{21}$

Por fim, o Doutor Evangélico, baseando-se num trecho da Carta aos Romanos, $\mathrm{XV}, 13$, em que o Apóstolo suplica a Deus que os cristãos daquela comunidade tenham esperança, gozo e fruam dos dons do Espírito Santo, arremata suas considerações sobre este assunto, afirmando que, os religiosos, ao praticarem aquele tríplice voto, devem, outro tanto, testemunharem aos demais fiéis que vivem as virtudes da confiança na Providência, que jamais desampara os seus filhos, do gozo do verdadeiro prazer, porque a castidade é permanente, não é efêmera, e da paz, que está em seus corações, porque alegres cumprem com seus compromissos e executam as incumbências que lhes foram atribuídas: "da esperança, quanto à pobreza, que só espera em Deus; o gozo, quanto à castidade, sem a qual não há gozo de consciência; da paz, quanto à obediência, fora da qual, seja quem for, não terá paz". ${ }^{22}$

Numa passagem dum outro sermão, aquele alusivo ao $2^{\circ}$ Domingo depois do Natal, o Santo, baseando-se, no trecho do Evangelho de Lucas II, 51, em que o Hagiógrafo fala que Jesus 'desceu com eles, e foi para Nazaré, e thes era submisso', e de outro, num versículo da Epístola aos Romanos XII, 3, em que Paulo afirma que, a respeito da fé, basta saber o que antes foi revelado ou o que, agora, lhes está sendo ensinado, realça simultaneamente a importância de o religioso observar 0 voto de obediência à sua Regra e aos seus superiores, consoante 0 exemplo de Cristo que foi "submisso [...] a um carpinteiro e a uma Virgem pobrezinha", e destaca a relevância quanto à prática da virtude da humildade da parte dos mesmos, pois, tendo-se em mente os insondáveis desígnios divinos, posto que no interior duma comunidade religiosa, as pessoas são tão diferentes umas das outras, conforme as suas respectivas maneiras de ser, qualidades e aptidões próprias, e ainda, provêm de famílias de condição social diversa, se "há sábios agregou-os Deus por meio dos simples. De facto, Deus escolheu as coisas loucas e ínimas, as coisas fracas e vis, a fim de por meio delas agregar os sábios, os fortes e os nobres, para que nenhum homem se glorie em si, mas naquele que desceu e foi para Nazaré e lhes era submisso. A Ele seja dada honra e glória por séculos eternos. ${ }^{23}$

$\mathrm{Na}$ verdade, a sabedoria divina é paradoxal. Com efeito, se hoje é muito raro encontramos nas Congregações religiosas um número expressivo de pessoas pertencentes às classes sociais mais abastadas e ou à intelectualidade, não o era, porém, à época de Sto. Antonio, e inúmeros foram os religiosos que oriundos da nobreza ou da burguesia emergente e da intelectualidade de então, ingressaram

$2^{2}$ Domingo depois do Natal, vol., II: 563 . 
na vida religiosa, e até mesmo no novel movimento franciscano, tendo se distinguido como frades exemplares. Para não nos afastarmos muito do assunto em exame, baste apenas mencionar como exemplos, Bernardo de Quintavalle, Pedro Cataneo e Alexandre de Hales. Certamente que, para tais pessoas, habituadas ao conforto, ao bem-estar, ao prestígio de que desfrutavam, era muito mais difícil praticar o tríplice voto, há pouco referido, bem como as virtudes da humildade, da simplicidade, da convivência fraterna e etc., não fossem a graça e o desígnio de Deus. Com efeito, quem julga que sabe muito, não interessa o campo de sua especialidade, toma-se, com freqüência soberbo e arrogante. Quem igualmente pertence a uma familia ilustre, fidalga ou rica, muitas vezes, cheio de orgulho, também se comporta de maneira prepotente, e ambiciona galgar cargos de direção. Por isso, o que importa, de fato, na conduta ética do religioso, entre outras atitudes corretas a serem vividas por ele, de acordo com a opção que fez, arremata o Santo, é "descer", quer dizer, ser humilde, "ir a Nazaré, sujeitar-se e obedecer perfeitamente [...]. Saber demais embriaga. Na embriaguez toda a sabedoria se torna insípida. Saber mais e discernir mais do que importa fazem 'errar o animal discreto, o noviço prudente, o sábio principiante' assim como erra o ébrio e o que vomita [...]. ${ }^{n 4}$

Entretanto, bem o sabia Santo Antônio, que não é fácil para ninguém seguir à risca o caminho da perfeição evangélica, de um lado, em face das próprias inclinações humanas, e de outro, devido aos sacrifícios que ela impõe, nomeadamente as vigílias de oração e de meditação, a frugalidade na alimentação, os jejuns, e outras formas de sacrificio, e ainda, o rigor da disciplina, os quais os religiosos igualmente estão obrigados a praticar. Por isso, ele lhes recomenda que orem com muito fervor ao Espírito Santo, para que lhes conceda a graça da perseverança naquele caminho que escolheram. ${ }^{25}$

Todavia, o Doctor Evangelicus muito apropriadamente, julga que não basta ao religioso praticar o tríplice voto, antes referido, bem como as virtudes supracitadas. Seu testemunho ao próximo tem de ser, ainda, mais completo. Por esse motivo, Santo Antônio, baseando-se na passagem do Evangelho de Mateus, V, 20, em que Cristo fala 'Se a vossa justiça não exceder à dos escribas e dos fariseus, não entrareis no reino dos céus', diz que "a justiça dos verdadeiros penitentes consiste no espírito de pobreza, no amor da fraternidade, no gemido da contrição, na mortificação do corpo, na doçura da contemplação, no desprezo da prosperidade terrena, no doce amplexo da adversidade, no propósito da perseverança final. ${ }^{26}$

Pensamos, no entanto, antes de tecer alguns comentários acerca dessas virtudes apontadas pelo Santo, como exigências relativas à conduta ética do religioso, ser necessário esclarecer dois termos, por ele utilizados, quais sejam, "justiça" e "penitentes". Nesta passagem, como em outras, o primeiro termo, mantendo sua conotação original, de cariz estóica, recolhido no Direito Romano, pelos Padres da Igreja, a saber, "dar a cada um o que lhe é devido", significa que os monges e os frades, consoante a vida que escolheram, têm de pautar o seu comportamento de acordo com aquelas exigências estabelecidas por Cristo, para quem

\footnotetext{
${ }^{24}$ Ibidem: vol., II: 562. 
escolheu o caminho da perfeição evangélica, caso contrário, não podem ser considerados verdadeiramente religiosos. Por sua vez, a palavra penitentes significa que quem escolheu percorrer tal caminho, deve altaneira e alegremente aceitar os sacrifícios que ele lhe impõe, porque essa vereda é, ainda, mais estreita e cheia de dificuldades do que a estrada que conduz à Bem-aventurança eterna, e por isso mesmo, um número considerável de pessoas a abandona.

Isto posto, naquela passagem o Santo Menorita quer dizer que os religiosos devem, ao praticar a pobreza, possuírem o seu espírito, isto é, serem desapegados dos bens materiais e igualmente livres do desejo de os ter; devem praticar intensamente a virtude da caridade entre si, aceitando o outro tal como ele o é, embora a convivência comunitária entre as pessoas, consoante à sua própria maneira e aos seus hábitos peculiares, muitos dos quais bem arraigados e profundos, absolutamente não seja tão natural e espontânea, como possa aparentar àqueles menos desavisados. É por essa razão, que o Santo, como vimos, recomenda ao religioso, para além da oração em que suplique a Deus perseverança no caminho em que escolheu, que, ainda, alegremente faça todo tipo de mortificações possiveis; despreze o mundo e seus atrativos, para que não seja tentado a prender-se aos mesmos, suporte com paciência os sofrimentos e as atribulações quotidianas, arrependa-se sempre dos pecados que está a cometer, e enfim, na hora derradeira, suplique insistentemente a Deus que lhe conceda a graça da esperança nas promessas de Cristo para o Seu servo bom e fiel.

O monge e o frade assim procedendo, e igualmente ainda, procurando imitar os exemplos e os conselhos dos Santos, dos Padres da Igreja, estão a contribuir efetivamente para a conversio e a regeneratio spiritualis do próximo, no âmbito do claustro ou do convento, de modo que, "reedifica o altar da fé, destruído pelos pecados, com as pedras das virtudes, em que se oferece um sacrifício de louvor". ${ }^{2}$

É por tal razão, que aqueles efetivamente autênticos estando a ver o comportamento mundano de um número considerável de clérigos regulares e seculares, bem como de uma quantidade muito maior de leigos, não só deploram tal fato, mas também se contristam por causa da "enfermidade de uns e outros, pois, 'nos verdadeiros religiosos há a sabedoria da contemplação, a lei do amor, a indignação [por causa] dos pecados' [...]". ${ }^{23}$

O religioso, como qualquer outra pessoa, embora pertencente à Ordo clenicorum, é um peccator que, entretanto, após converter-se e se arrepender de seus pecados/vícios, graves ou leves, toma-se um poenitens que aspira à regeneratio spiritualis, isto é, vir a ser um homo renatus ou novus, mediante o Sacramento da Penitência.

Ora, como se sabe, este Sacramento implica, entre outras atitudes da parte do confitente, uma inicial, o arrependimento sincero das faltas cometidas, a par do propósito de se converter ou mudar a maneira de proceder, e uma outra, final, a satisfação ou penitência, que consiste em ele reparar os pecados cometidos em relação a Deus e ao próximo, mediante a efetivação de determinadas boas obras, que espelham justamente o começo de sua nova maneira de viver.

27 6 Domingo depois de Pentecostes, vol., I: 681 .

28 $3^{e}$ Domingo do Advento, vol., II: 471. Cfr. também Glo. Int., ad Tob. IV, 16. 
Com efeito, Santo Antônio, numa passagem constante do sermão alusivo ao $2^{2}$ Domingo depois da Epifania, também fala nãa só a respeito de como os religiosos devem cumprir com a satisfação que lhes foi imposta pelo confessor, em reparação de seus pecados, mas ainda, acerca de qual deve ser todos os dias a sua conduta ética, de acordo com o status perfectionis evangelicae que abraçaram.

$\mathrm{Na}$ verdade, ele, apoiando-se no trecho do Evangelho de Mateus, VIII, 1-4, lido na missa do dia, em que o Evangelista narra o milagre de Jesus curando um leproso, e de outro, no texto do Levítico, XIV, 1-7, 10, 21-23, que prescrevia- se a oferenda que o restabelecido daquela doença devia fazer a Deus, entende e recomenda que a satisfação da parte dos religiosos deva ser mais rigorosa porque é de justiça que assim seja, dada a opção de vida que fizeram. Ora, posto que esta consiste, primeiramente, na doação total de si mesmo a Deus, como prova de amor para com Ele, depois, na observância à risca, da pobreza, da caridade fraterna para com os confrades, da obediência e humildade, e ainda, na prática de variados sacrifícios, porque eles purificam o corpo e o espírito, e ajudam o religioso a meditar e a contemplar mais facilmente os bens supemos, deverá, ele, outrossim, diariamente praticar a mansidão, oposta à ira, a simplicidade, contrária à vanglónia, a humildade, oposta à soberba, manifesta na tríplice obediência, e em relação a todos os semelhantes, as conhecidas seis obras de misericórdia. A propósito, eis as suas palavras: "As duas aves vivas são o corpo e o espírito do religioso, que pode dizer com o Apóstolo: 'Vivo eu, mas já não sou eu que vivo, pois é Cristo que vive em mim'. Oferece ao Senhor estas aves pela sua purificação.

Deve também oferecer pau de cedro, que designa a pobreza, escarlate, que designa a caridade, e hissopo, que designa a humildade [...] e 'imolará umas aves', o corpo, a fim de dizer com o Apóstolo: 'O mundo está crucificado para mim, e eu para o mundo' [...]. O religioso, portanto, imola a ave em vaso de barro sobre água viva quando crucifica o seu corpo com os vícios e concupiscências e repensa, de alma amargurada, a fragilidade da vida e a calamidade do exilio [...] e 'imolará a outra ave viva'. A ave viva é o espírito [...] a mortificação e maceração do corpo, que se designa no sangue, limpa e santifica o espírito, e assim voa com as asas da contemplação juntamente com as sobreditas virtudes para o campo, para o céu [...]' e tomará dois cordeiros sem mancha'. Os dois cordeiros designam a mansidão do espírito e do corpo; a ovelha a intenção simples e pura em todas as obras; as três dizimas de flor de farinha, a tripla obediência: [ao] superior, [ao] igual e [ao] inferior; as seis talhas de azeite, as seis obras de misericórdia. Esta é a oblação que todo o religioso deve oferecer pela purificação do seu pecado. ${ }^{n 9}$

Enfim, Santo Antônio também fala algo a respeito da recompensa, na outra vida, a ser atribuída pelo Senhor ao bom religioso: "depois de o juiz supremo ter examinado perfeitamente as palavras, os actos e toda nossa vida [...] [nos fará] imortais e bem-aventurados [...] para que...cantemos, dando graças eternamente: 'O Senhor é Deus'." 
O programa ético antoniano para os religiosos em seus Sermones Festivi, encontra-se apenas num trecho da prédica alusiva à festa da Conversão de São Pau10. O Santo Franciscano, baseando-se em Mateus, XIX, 27-29, em que está escrito que 'Naquele tempo, Simão Pedro disse a Jesus: eis que nós abandonamos tudo e te seguimos. O que haverá então para nós ? Jesus, porém, lhes disse: em verdade, em verdade vos digo, que vós que me seguistes, no dia da regeneração, quando o Filho do homem estiver sentado, no trono da sua majestade também vós estareis sentados sobre doze tronos', e pondo esta passagem em consonância com um versículo de Isaías, XIV, 22, 'Destruirei o nome de Babilónia, as suas reliquias e o renovo e toda a sua raça', toma, primeiramente, a explanar sobre o que é a vida religiosa, que se alicerça no amor a Deus acima de tudo, dando ênfase especial ao voto e à prática da pobreza: "O nome Babilónia é um nome de propriedade, como meu e teu. Cristo não só destruiu nos Apóstolos este nome, mas as relíquias de propriedade, e não só isto, mas ainda o renovo, isto é, a tentação de possuir, e a raça, isto é, a vontade de possuir. Felizes aqueles religiosos, em que estas coisas são destruídas, porque verdadeiramente poderão dizer: 'eis que deixamos tudo' [...]." ${ }^{31}$

Com efeito, tamanha foi a atração e a sedução que Cristo exerceu sobre os Apóstolos, que eles, impelidos por um profundo amor à Sua Pessoa, foram capazes de, não só renunciar completamente à propriedade sobre todos os bens que possuiam, mas também de não mais se recordar dos mesmos, e igualmente, não se deixar tentar pelo desejo de os ter de novo. De igual modo também deve proceder o verdadeiro religioso, no que concerne à pobreza por opção, radicada no amor a Deus e ao próximo.

Um pouco mais adiante, apoiando-se num trecho do Livro de Jó, XXXVI, 16: 'Porventura conheces os grandes caminhos das nuvens e a ciência perfeita?', o Santo, reitera em que consiste abraçar o caminho da perfeição evangélica, em particular, a respeito da pobreza voluntária, por amor a Cristo, destacando, como exemplo, a maneira de viver dos primeiros Menoritas, imitadores dos Apóstolos: "O grande caminho é tudo abandonar. Tal caminho é estreito enquanto somos peregrinos, é grande quando recebemos a retribuição; a ciência perfeita é amar a Jesus e ir atrás dele".

Por isso, "Os Apóstolos e os varões apostólicos são como pombas 'simples' e inocentes. Voaram dos bens terrenos 'para guardarem as janelas dos sentidos', a fim de por meio delas não saírem para os bens exteriores, que abandonaram". ${ }^{32}$

O Frade lusitano, prosseguindo na explicação daquela passagem de Lucas, em seguida, ressalta que abraçar a vida religiosa ou o caminho da perfeição evangélica impõe àquele que o escolheu um profundo amor a Cristo, que implica uma entrega total a Ele. Por isso, diz o Santo "muitos deixam as suas coisas, e todavia não seguem a Cristo, porque [...] não se dão a si mesmos. Se queres seguir e conseguir, importa que te deixes. Aquele que segue a outro no caminho, não olha para si, mas para aquele a quem constituiu guia da sua vida. Abandonar-se é não confiar em nada de si. ${ }^{\text {n3 }}$

31 79 Sermão festivo Conversão de São Paulo, vol., II: 727-728.

32 Ibidem, vol., II: 729. Cfr. também Glo. Int., ad Is., l.c.

33 Ibidem: 730 . 
De fato, Cristo é para o religioso o tesouro mais precioso de que ele necessita, porque, no dizer de Antônio, Ele é "A sabedoria [que] cria todas as coisas; a prudência [que] governa as criaturas; a força [que] refreia o diabo; a inteligência [que] penetra todas as coisas; a longevidade perpetua [para] os seus; o sustento [que] sacia; a luz [que] clarifica; a paz [que] tranquiliza", ${ }^{34}$ de modo que 0 monge e 0 frade conhecendo e amando plenamente a Jesus, sabe o que é fazer o bem, dominar suas inclinações corporais e ajudar os seus irmãos a fazer o mesmo, e para tanto, conta com a Sua graça, através da qual, coíbe a ação do demônio no mundo. Ele é, outrossim, a inteligência, por intermédio da qual eles têm acesso à verdadeira sabedoria sobre tudo o que importa saber; Ele é a longevidade, através da qual eles prolongam a Vida plena daqueles que estão à sua volta; Ele é o sustento, mediante o qual encontram em Sua palavra e em Seu corpo e sangue o alimento para continuar sua caminhada permanente à perfeição; Ele é a luz, por intermédio da qual, eles são iluminados em sua caminhada neste mundo; Ele é a paz, que lhes dá a tranqüilidade de espírito.

Por último, num passo deste mesmo sermão, Santo Antônio também fala da recompensa especíica que o bom religioso irá receber no dia do Juízo, consoante a missão e o ministério que exerceu aqui na terra: "aos que o seguem desta maneira: 'no dia da regeneração, quando o Filho do homem estiver sentado, no trono da sua majestade também vós estareis sentados sobre doze tronos' $[\ldots]^{\prime \prime} .{ }^{3}$

Do que foi exposto, pudemos verificar que Santo Antônio mantém nas duas partes de sua opera uma coerência doutrinal não apenas quanto aos ensinamentos acerca de como deve ser o comportamento ético do religioso, tanto de seu tempo, e certamente ainda, aplicável aos de nossa época e aos de amanhã, e com a própria concepção que tinha acerca do homo christianus singularmente considerado, e como membro da Ecclesia. Com efeito, embora, a finalidade imediata da Ordo clericorum seja propiciar todos os meios para os fiéis alcançarem a Bemaventurança eterna, cuja caminhada terrena principia com a sua própria conversio e regeneratio spiritualis, quer através da oração, da pregação e da distribuição dos Sacramentos, e igualmente através de outras tantas práticas devocionais, o clérigo regular há de fazer tudo isso, mas tem, ainda, o compromisso religioso e moral de, vivendo em comunidade, observar à risca o tríplice voto que professou, ao ter escolhido a via perfectionis evangélica, ${ }^{36}$ por amor a Deus e ao próximo, e ainda, praticar sempre determinadas virtudes, antes referidas, cuja vivência redunda, não só em exemplo de edificação para todas as outras pessoas que estão particularmente junto de si, e daquelas com quem se relaciona, ao desempenhar o seu ministerium, mas também em proveito da Ordo a que pertence, de toda a Igreja, e do Corpo Místico de Cristo.

Ibidem: 730 .

${ }^{35} 7^{2}$ Sermão festivo Conversão de São Paulo, vol., II: 731. Cfr. também Mt XIX, 27-29.

36 T. De POI, "Teologia del Sacerdozio e della vita religiosa nei Sermoni Antoniani", Atti del Congresso Intemazionale di Studio sui Sermones di S. Antonio di Padova, a cura di A. Poppi, Pádua, Ed. Messaggero, 1982, p. 631: "Dalla sua formazione tra i canonici regolari coglie la vita religiosa che ha come elemento fondamentale e caratterizzante i tre consigli evangelici. Dalla conoscenza della Regola di S. Francesco, poi, e dalla esperienza della prima generazione francescana, egli coglie la vita religiosa come 'sequela' di Cristo...imitazione di Cristo, ma imitazione di Cristo povero, casto, obbediente [...]." 